\title{
Firm Level Determinants of Capital Structure: Evidence From Egypt
}

\author{
Ahmed Sakr ${ }^{1} \&$ Amina Bedeir ${ }^{2}$ \\ ${ }^{1}$ Department of Finance and Accounting, College of Management and Technology, Arab Academy for Science and \\ Technology, Alexandria, Egypt \\ ${ }^{2}$ Post Graduate Department, College of Management and Technology, Arab Academy for Science and Technology, \\ Alexandria, Egypt \\ Correspondence: Amina Bedeir, Arab Academy for Science and Technology and Maritime Transport, College of \\ Management and Technology, P.O.Box 1029, Miami, Alexandria, Egypt.
}

Received: October 17, 2018

Accepted: January 3, 2019

Online Published: January 9, 2019

doi:10.5430/ijfr.v10n1p68

URL: https://doi.org/10.5430/ijfr.v10n1p68

\begin{abstract}
The purpose of this paper is to investigate the firm level determinants of capital structure of Egyptian publicly traded non-financial firms. The study investigates the firm level determinants of capital structure of Egyptian companies utilising data from the financial statements of 62 listed companies over the time period from 2003 to 2016. The study investigates whether the capital structure decisions in Egypt are closer to the assumptions of Trade-Off Theory, of Pecking Order Theory or of the Agency Cost Theory. The empirical evidence obtained allows us to conclude that Trade-Off and Pecking Order Theories are the most theories to describe the financial behaviour of the Egyptian companies' choice of capital structure whereas there was little evidence to support the agency cost theory.
\end{abstract}

Keywords: Egypt, capital structure, trade-off theory, pecking order theory, firm level, emerging markets

\section{Introduction}

Capital structure is one of the most crucial subjects in finance field, and the most widely researched topic academically as well as professionally. As the way a firm is financed is very important to investors, directors, stakeholders and all parties interested in the firm; because of the direct impact financing decisions have on the firm's value. The literature on corporate capital structure and its determinant is very famous with its three theories; its foundation can be traced to the work of Modigliani and Miller (1958; 1963). Starting with the assumption of perfect markets, Modigliani and Miller (1958) state that the use of either debt or equity funding in financing decision are not relevant to increase the market value of the firm. From this proposition, a series of both theoretical and empirical investigations have been developed resulting in a well corroborated theory in financing a firm's assets.

There're mainly three theories explaining the capital structure: Trade-off Theory, Pecking Order Theory (Information Asymmetry), and Agency Cost Theory (Free Cash Flow). These theories are known as traditional theories of capital structure; each offers distinctive explanation for corporate financing than the other two theories. The Trade-off Theory assumes the existence of an optimal capital structure; it focuses on the trade-off between marginal benefit of debt (debt tax shields or tax saving) and the marginal cost of debt (bankruptcy costs). On the other hand, the Pecking Order Theory assumes hierarchal financing decisions first the use of internal financing sources, and then the firm seeks external financing from debt if the internal sources are less than the investments requirements, and at last the use of equity as the last source. The Agency Cost Theory proposes that, debt represents a fixed obligation that must be met by the firm as the debt interest and principals have to be paid. It's assumed that these obligations prevent managers from the over consumption of the firm's financial resources, as it take over the firm's free cash flow if exists.

Traditionally, majority of researches focused on only the firm's attributes in their analysis of the corporate capital structure determinants such as Miller (1977), Qureshi (2009), Sheikh and Wang (2011), and Titman and Wessels (1988). In the meantime, while explaining the corporate capital structure researchers classify the determinants of capital structure into three attributes; firms' attribute, industry's attributes and country's attributes (Jong et al., 2008).

As developed countries have better economic, legal, and financial systems, they provide companies operating within a better, easier and cheaper access to external finances sources. On the other hands, it is very essential to study the capital structure in Egypt in order to examine whether there are differences or similarities between capital structure 
decisions in Egypt as an emerging market and the capital structure decisions of both developed and developing countries.

The importance of this study is that, financing decisions have a direct influence on the firm's value; also, to the best of our knowledge there are a few researches and studies that have been conducted on capital structure in developing countries, thus this research will enrich the subject. The study also attempts to boost the understanding about the capital structure behaviour of the firms in developing countries by taking Egypt as a sample case. For such purpose, a panel data set (2003-2016) of 62 listed non-financial firms resulting in 868 observations has been developed.

Confirming earlier studies in emerging countries specifically Middle East countries (Omet and Mashharawe, 2004; Qureshi, 2009; Sheikh and Qureshi, 2014; Abdulla, 2017; Kumar, Colombage \& Rao, 2017), the results display that firms prefer the use of equity financing their projects and debt is easily available for experienced firms with preference of the use of short-term debt over long-term debt. Further, these firms follow a mix of two capital structure theories: trade-off theory and pecking order theory; while little evidences support the agency cost theory. Moreover, the study contributes to the literature in general and specifically in Egyptian context.

\section{Literature Review and Hypotheses Development}

\subsection{Theories of Capital Structure}

Starting with the famous paper of Modigliani and Miller (1958), stating that the choice of equity and debt is irrelevant; assuming that capital markets are perfect where insiders and outsiders share free access to information, no transaction cost, bankruptcy cost and no taxation exist; thus, internal and external funds can be perfectly substituted. They brought up the direction that such theories followed on revealing under what conditions capital structure is irrelevant. They also provided evidence that in perfect capital markets, the choice between debt and equity financing has no significant effect on the firms' value. Thus, financial managers should not be concerned about the proportion of debt and equity; as any combination will be very similar to another. Several studies have examined the empirical validity of the theories of capital structure, there's no universal well accepted theory within the developed economies context and no reason to expect one (Myers, 2001). This is may be due the fact that the orientation of each theory is different.

The trade-off theory (Modigliani and Miller, 1963, Schwarz and Aronson, 1967, and Gupta, 1969) is one of the most three influential theory of capital structure, it focuses on the trade-off between debt tax shields or tax saving and bankruptcy costs; and assuming the existence of an optimal capital structure. It emerged from ceasing the assumption of absence of bankruptcy costs in the MM theory by some studies, stating that when the net tax advantage of debt financing and the leverage related costs such as bankruptcy are balanced, optimal capital structure exists.

The pecking order theory introduced by Donaldson 1961 is based mainly on two prominent assumptions. First the information asymmetry, as managers are better informed about their own firm's prospects than outside investors. Second, managers acts in the best interest of existing shareholders. So, the pecking order theory assumes hierarchal financing decisions (Myers, 1984); first the firms use internal sources of financing, and then seek external sources of financing from debt if the internal sources are less than the investments requirements, and at last use the equity as the last source. The pecking order theory assumes that; if the firm is profitable enough to substitute debt financing by internal sources of financing through the use of accumulated retained earnings, this doesn't mean that the firm can reach the maximum debt ratio. Also, it assumes the existence of both market inefficiency, and asymmetric information in the financial markets, that's why a firm will have no well-defined target capital structure under this theory. These imperfections influence corporate finance policy.

On the other hands, the Agency Cost Theory is concerned with the relationship between the principal (shareholders) and the agent of the principal (managers); it states the relationship and conflicts between the shareholders and the firm's manager that arises from financing with risky debt; by minimising costs arising from such conflicts an optimal capital structure can be determined. This theory (Jensen and Meckling, 1976) proposes that, debt represents a fixed obligation that must be met by the firm as the debt interest and principals have to be paid. It's assumed that these obligations prevent managers from the over consumption of the firm's financial resources, as it take over the firm's free cash flow if exists.

Hams and Raviv (1991) state that it's very crucial that empirical studies focus on testing particular models or classes of models while attempting to detect the most important determinants of capital structure in given environments. Also, Gleason et al. (2000) argue that legal and tax environment, the economic system, as well as technological capabilities all influence the capital structure of retailers in the 14 European countries they have examined. As majority of capital structure theories are based on data from developed countries mainly from the United States, 
while few studies provide evidence from developing countries. It is important to identify factors affecting those decisions since capital structure is very crucial to back up a firm's financial and operating decisions. To identify these factors; three main groups have been defined based on the implicit effects of these variables; these groups of factors are: firm specific factors, industry specific factors, and country specific factors. This paper focuses mainly on the firm specific determinants of capital structure. Since firm-specific factors do not follow a particular direction of relationship with leverage. Many studies reveal diverse results, thereby providing mixed yet confusing evidence about capital structure decisions.

Firm-specific factors include several factors each have many proxies discussed in numerous studies, while the most common factors that have been used in almost every studies about capital structure determinants are: profitability of the firm, size, tangibility, liquidity, growth, business risk, and financial flexibility.

Egypt is one of the most diversified economies in the Middle East, and one of the top haven for emerging market, this motivates studying capital structure to examine the effect of firm level determinants of capital structure. Conforming to the results of Eldomiaty (2007) in his study in Egypt, he shows the relevance of both the trade-off and pecking-order theories. However, these results are not similar to the findings of Omet and Mashharawe's (2004), who studied the determinants of capital structure in Jordan, Kuwait, Oman, and Saudi Arabia for the period 1996-2001. They imply that the pecking-order theory is relevant even in Middle East countries, such as Jordan, which had the lowest level of long-term debt among the other Gulf countries, implying that the trade-off theory is not relevant.

To sum up, only few papers have investigated the capital structure of Egyptian firms from different points; what was unnoticed and what our paper aims to achieve is a complete inclusive view of the whole picture of determinants of capital structure in Egypt.

\subsection{Development of Hypotheses and Determinants of Capital Structure}

The hypotheses development is built on two arguments. First, the expectation of similar results as those from studies conducted in Middle East countries, sharing similar institutional characteristics. Second, taking into considerations the results of research conducted by Eldomiaty, (2007); we investigate the three theories over a period of fourteen years prior and post to the financial crisis although we predict the dominance of both the trade-off theory and the pecking order theory based on the results found by Eldomiaty, (2007).

For profitability, according to proposition of the trade-off theory there's a positive relationship between profitability and leverage; Urn (2001) states that higher levels of profit lower the probability of bankruptcy giving rise to higher incentives to use tax shields, thus leading to a higher level of debt. Whereas a negative relationship between debt and profitability is consistent with the pecking order theory such relationship has been found in studies conducted in the Gulf countries (Omet and Mashharawe, 2004; Ayyash et al., 2013; Farooq, 2015). The reason behind this negative relationship is that highly profitable firms prefer to use their retained earnings and consequently do not need external funding, as shown by Bevan and Danbolt (2002), Rajan and Zingales (1995) and Titman and Wessel (1988). The above arguments lead to the following hypothesis:

\section{H1: There is a significant relationship between leverage and Profitability.}

The pecking-order theory suggests that size of the firm will negatively affect leverage because large firms have more internal funds and thus need less external funding (Titman and Wessel, 1988). On the contrary, a positive relationship between leverage and size proposed by the trade-off theory, Rajan and Zingales (1995) argue that the size of the firm can be viewed as an inverse proxy for bankruptcy. As leverage increases with size, the chance of bankruptcy decreases. The same argument has been confirmed by Barclay et al. (1995) and Bevan and Danbolt (2002), and in Gulf countries by Omet and Mashharawe (2004). The above arguments lead to the following hypothesis:

\section{H2: There is a significant relationship between leverage and size.}

With regards to tangibility; the three capital structure theories agreed upon a positive relationship between tangibility and leverage, since tangible assets can be used as collateral. Titman and Wessel (1988) and Walsh and Ryan (1997) find evidence for these predictions. Although the pecking-order theory predicts that leverage is positively influenced by tangibility, yet there is no empirical evidence for this from the Gulf countries.

H3: There is a positive relationship between leverage and tangibility.

With regards to liquidity The trade-off theory suggests a positive relationship between liquidity and leverage, due to the fact that the trade-off theory proposes that firms with higher liquidity ratios should borrow more in order to be 
able to meet their current contractual obligations when it is due (Rajan and Zingales, 1995). On the other hands, both pecking order and agency cost theories suggest a negative relationship between liquidity and leverage, as firms with higher liquidity prefers to use internal sources of finance (i.e. retained earnings) while financing its new investments (in regards to the pecking order theory). Additionally, the agency cost theory justifies the negative relation by the potential conflict between shareholders and debtholders (Jensen and Meckling, 1976; Myers, 2001; Ramadan, 2009). However, major empirical studies showed negative relationship between liquidity and debt ratios (Deesomsak et al., 2004; Mazur, 2007; Viviani, 2008); such negative relationship may possibly be the outcome of excessive liquidity maintained by the firms which encourage managers to consume more than the optimal level of perquisites.

\section{H4: There is a significant relationship between leverage and liquidity.}

As firms with high growth opportunities have greater bankruptcy and agency costs, those firms can be unwilling to use high amounts of debt in order to avoid the likelihood increase of bankruptcy Myers (1984). That's why; the financial managers of those firms may not choose debt as the first financing option. Both trade-off and agency cost theories propose that growth opportunities have a negative impact on leverage, because the intangible assets (growth opportunities) cannot be collateralised (Myers, 2001; Sheikh and Wang, 2011). Conforming to the trade-off theory, firms with greater growth opportunities have a lower level of debt, given that greater investment opportunities increase the possibility of agency problems between shareholders and creditors, because the former have a great incentive to underinvest (Myers 1977). On the contrary, the pecking order theory proposes that growth opportunities should have a positive influence on debt (Myers, 1984). Due to the asymmetric information assumption between managers and outside investors and the firms with higher growth opportunities than the owned assets (specifically small firms) involves a higher demand of debt finance. That's why the pecking order theory proposes for a positive relationship between growth opportunities and debt level (DeAngelo and Masulis, 1980; Jensen, 1986; Myers, 1984; Myers and Majluf, 1984).

\section{H5: There is a significant relationship between leverage and growth opportunities.}

ElKelish and Marshall (2007) argue that business risk has a negative significant relationship with leverage. However, several studies have shown negative relationship between risk and capital structure, that is a firm's leverage is decreased when risk increaes (Eldomiaty, 2007; Sheikh and Wang, 2011; Low and Chen, 2004; Abor and Biekpe, 2009; Al-Najjar and Taylor, 2008; Chung, 1993; Heshmati, 2001).

The existence of a negative relationship between risk and capital structure supported by the trade-off theory that suggest that risky firms or high probability of default firms should not be levered (Wiwattanakantang, 1999; Titman and Wessels, 1988). This may be due to the fact that the increase in business risk potentially is associated with increase in bankruptcy risks (Burgman, 1996). The results of some empirical studies showed a positive relationship between risk and long-term debt (Nguyen and Ramachandran, 2006; Kaur and Rao, 2009). Jordan et al. (1998) concluded that the positive relationship between risk and market value of debts when market has a higher growth.

\section{H6: There is a negative relationship between leverage and business risk.}

Marsh (1982) argues that financial flexibility of a firm affects the firm's target debt ratio. Both the trade-off theory and the pecking order theory suggest a negative relationship between financial flexibility of the firm and the level of leverage. This is due to the fact that managers of more profitable firms prefer the use of internal funding over external sources of finance (Myers and Majluf, 1984). Beattie et al. (2006) propose that by increasing the financial flexibility of firm; these firms tend to have less debt and avoid the need for external financing. Furthermore, other researchers concluded that financial flexibility is a key determinant of optimal capital structure, which is consistent with the trade-off theory (Graham and Harvey, 2001; Brounen et al., 2005). However, Eldomiaty (2007) did not observe any relationship between financial flexibility of firms and capital structure.

\section{H7: There is a negative relationship between leverage and financial flexibility.}

\section{Description of Data and Methodology}

\subsection{Data}

The study uses annual data of non-financial listed companies in the Egyptian Stock Exchange during the period 2003:2016 through 3 stages; first we take the whole 14 years, then we measure from 2003 till 2008 and from 2009 till 2016 as a way to investigate the effect of the financial crisis as well as the effect of the revolution and the subsequent political and economic crisis in Egypt. We exclude the financial companies and the banking sector due to the uniqueness of their capital structure and the strict legal requirements for their financing choices (Gaud et al., 2005) in line with most previous literature. The Egyptian Stock Exchange has 251 listed companies in 2016 
representing 17 different sectors. The majority of companies are in the food and beverage and the industrial goods and services sectors. Our final sample consists of 62 Egyptian companies was obtained for a period of 14 years resulting in 868 observations and covering 12 industries, the Table 1 summarises the classification of firms across the various industries. The main source for the data used is the Egyptian Stock Exchange (EGX) and the Egyptian Financial Regulatory Authority (EFRA) as they contain the authorized information for listed companies as well as the different Industries.

Table 1. Classification of the used sample of listed companies

\begin{tabular}{ll}
\hline Sector & No. of Firms in the Sector \\
\hline Basic Resources & 2 \\
\hline Chemicals & 3 \\
\hline Construction and Materials & 4 \\
\hline Oil and Gas & 2 \\
\hline Food and Beverage & 16 \\
\hline Healthcare & 8 \\
\hline Media & 1 \\
\hline Industrial Goods and Services & 12 \\
\hline Personal and Household products & 8 \\
\hline Technology & 1 \\
\hline Travel and Leisure & 1 \\
\hline Real Estate and Housing & 4 \\
\hline Total & 62
\end{tabular}

Note: This table presents the industrial classification of the firms listed in Egypt Stock Exchange and included in the sample

\subsection{Empirical Models}

The main model to investigate the impact of firm level determinants of capital structure is as follow:

$$
\mathrm{L}_{\mathrm{i} . \mathrm{t}}=\beta_{0 \mathrm{i}, \mathrm{t}}+\beta_{1} \text { FPROF }_{\cdot \mathrm{i}, \mathrm{t}}+\beta_{2} \text { FSIZE }_{\cdot \mathrm{i}, \mathrm{t}}+\beta_{3} \text { FTANG }_{\cdot \mathrm{i}, \mathrm{t}}+\beta_{4} \text { FLIQ }_{\cdot \mathrm{i}, \mathrm{t}}+\beta_{5} \text { FGRO }_{\cdot \mathrm{i}, \mathrm{t}}+\beta_{6} \text { FBRISK }_{\mathrm{i}, \mathrm{t}}+\beta_{7} \text { FFLEX }_{\cdot \mathrm{i}, \mathrm{t}}+\varepsilon_{\mathrm{i} . \mathrm{t}}
$$

$\mathrm{L}_{\mathrm{i} . \mathrm{t}}$ : is a measure of leverage taken as TD/TA (Rajan and Zingales, 1995; Titman and Wessel, 1988); and SD/TA (Chung, 1993; Booth, Aivazian \& Demirguc-Kunt 2001; Shumway, 2001; Fama and French, 2002; Colombo, 2001;

Bevan and Danbolt 2002) for firm (i) at time (t); $\varepsilon_{i . t}$ is the random error.

We use seven key firm level determinants of capital structure as in previous studies: profitability, growth, size, tangibility, liquidity, business risk, and financial flexibility. The measure of each of these variables are shown in Table 2 which summarizes the firm level capital structure determinants examined in this study, the ratio or proxy for each determinant, and the previous related studies support the use of each measure.

Table 2. Measures of the firm level determinants of capital structure

\begin{tabular}{|c|c|c|}
\hline $\begin{array}{l}\text { Determinant of } \\
\text { Capital } \\
\text { Structure }\end{array}$ & Measure & Empirical Evidence / Support \\
\hline $\begin{array}{l}\text { Profitability } \\
\text { FPROF. }\end{array}$ & $\begin{array}{l}\text { Earnings before } \\
\text { interest, taxes and } \\
\text { depreciation } \\
\text { total assets }\end{array}$ & $\begin{array}{l}\text { Al-Ajmi et al. (2009); Kaur and Rao (2009); Nunkoo and Boateng (2010); } \\
\text { Zhang (2010); Rajan and Zingales (1995); Michaelas et al. (1999); Fama } \\
\text { and French (2002); Cassar and Holmes (2003); Sogorb-Mira (2005); } \\
\text { Mazur (2007); Daskalakis and Psillaki (2008); Antoniou et al. (2008); }\end{array}$ \\
\hline
\end{tabular}


$\Delta$ EBITDA $_{t}$

Frank and Goyal (2009); Chakraborty (2010); Arvanitis et al. (2012); Van Caneghem and Van Campenhout (2012).

\begin{tabular}{ll}
\hline Size & Natural logarithm of \\
FSIZE & total assets \\
& LnAssets $t$
\end{tabular}

Michaelas et al. (1999); Sogorb-Mira (2005); Nguyen and Ramachandran (2006); Antoniou et al. (2008); Abor and Biekpe (2009); Al-Ajmi et al. (2009); Bevan and Danbolt (2000); Črnigoj and Mramor (2009); Pathak (2010); Zhang (2010); Sheikh and Wang (2011); Titman and Wessels (1988); Hall et al. (2004); and Chakraborty (2010).

Tangibility Fixed assets to total Michaelas et al. (1999); Antoniou et al. (2008); Sogorb-Mira (2005); Abor FTANG. assets and Biekpe (2009); Bevan and Danbolt (2000); Frank and Goyal (2009); FATA $_{t}$ Chakraborty (2010); Cortez and Susanto (2012); Arvanitis et al. (2012); Moosa et al. (2011); Nguyen and Ramachandran (2006); Al-Ajmi et al. (2009); Karadeniz et al. (2009); Črnigoj and Mramor (2009); Sheikh and Wang (2011).

\begin{tabular}{|c|c|c|}
\hline $\begin{array}{l}\text { Liquidity } \\
\text { FLIQ. }\end{array}$ & $\begin{array}{l}\text { Current Ratio } \\
\text { CRt }\end{array}$ & $\begin{array}{l}\text { Bradley et al. (1984); Kaurand Rao (2009); Mazur (2007); Pathak (2010); } \\
\text { Sheikh and Wang (2011); Alom (2013). }\end{array}$ \\
\hline $\begin{array}{l}\text { Growth } \\
\text { FGRO. }\end{array}$ & $\begin{array}{l}\text { Growth of Total } \\
\text { Asstes } \\
\Delta \% \mathrm{TAt}\end{array}$ & $\begin{array}{l}\text { Michaelas et al. (1999); Sogorb-Mira (2005); Nguyen and Ramachandran } \\
\text { (2006); Al-Ajmi et al. (2009); Bevan and Danbolt (2000); Črnigoj and } \\
\text { Mramor (2009); Pathak (2010); Odit and Gobardhan (2011). }\end{array}$ \\
\hline $\begin{array}{l}\text { Business Risk } \\
\text { FBRISK }\end{array}$ & $\begin{array}{l}\text { Percentage change of } \\
\text { Earnings before } \\
\text { Interest and Taxes to } \\
\text { Total Assets } \\
\Delta \% \text { EBITTAt }\end{array}$ & $\begin{array}{l}\text { Michaelas et al. (1999); Sogorb-Mira (2005); Nguyen and Ramachandran } \\
\text { (2006); Al-Ajmi et al. (2009); Bevan and Danbolt (2000); Črnigoj and } \\
\text { Mramor (2009); Pathak (2010); Odit and Gobardhan (2011). }\end{array}$ \\
\hline $\begin{array}{l}\text { Financial } \\
\text { Flexibility } \\
\text { FFLEX. }\end{array}$ & $\begin{array}{l}\text { The Expected effect } \\
\text { of Retained Earnings } \\
\text { REA } t+1\end{array}$ & $\begin{array}{l}\text { Graham and Harvey (2001); Brounen et al. (2005); Eldomiaty (2007); } \\
\text { Al-Ajmi et al. (2009); Bokpin (2009). }\end{array}$ \\
\hline
\end{tabular}

\section{Results}

This section first presents the descriptive statistics, correlation matrix, and VIF results; then discusses the main results; and finally compares these results with those found in Middle East and emerging countries.

\subsection{Descriptive Statistics}

Table 3 presents the descriptive statistics over the three ranges of time; from these results, we can conclude the following:

Table 3. Descriptive statistics

\begin{tabular}{llllllll}
\hline Variable & Mean & Median & Std. Dev. & Min. & Max & Skewness & Kurtosis \\
\hline Period 2003:2016 & & & & & & & \\
\hline Total Debt to Total Assets & 0.46 & 0.44 & 0.28 & 0.002 & 1.05 & 0.17 & -0.74 \\
\hline Long-Term Debt to Total Assets & 0.08 & 0.02 & 0.17 & .001 & 0.98 & 5.57 & 17.02 \\
\hline Short-Term Debt to Total Assets & 0.38 & 0.36 & 0.22 & 0 & 0.99 & 0.92 & 3.55 \\
\hline Profitability & 0.21 & 0.13 & 0.24 & -0.38 & 1.53 & 1.64 & 3.70 \\
\hline Size & 20.25 & 20.10 & 1.68 & 13.28 & 25.28 & 0.17 & 0.24 \\
\hline Tangibility & 0.28 & 0.25 & 0.21 & .0004 & 0.90 & 0.71 & -0.21 \\
\hline Liquidity & 2.60 & 2.46 & 1.41 & 0.27 & 7.86 & 1.64 & 2.38 \\
\hline Growth & 0.13 & 0.04 & 0.55 & -0.89 & 9.83 & 9.54 & 13.48 \\
\hline
\end{tabular}




\begin{tabular}{llllllll}
\hline Business Risk & -0.048 & -0.041 & 1.433 & -8.22 & 8.48 & 0.078 & 11.25 \\
\hline Financial Flexibility & 0.029 & 0.011 & 0.17 & -1.037 & 0.735 & -2.85 & 16.36 \\
\hline Period 2003:2008 & & & & & & & \\
\hline Total Debt to Total Assets & 0.49 & 0.50 & 0.28 & 0.002 & 1.003 & -0.03 & -0.45 \\
\hline Long-Term Debt to Total Assets & 0.08 & 0.02 & 0.17 & .011 & 0.98 & 5.99 & 14.13 \\
\hline Short-Term Debt to Total Assets & 0.40 & 0.39 & 0.21 & 0 & 0.99 & -0.02 & -0.62 \\
\hline Profitability & 0.22 & 0.15 & 0.23 & -0.34 & 1.48 & 1.46 & 3.15 \\
\hline Size & 19.92 & 19.80 & 1.74 & 13.28 & 25.28 & 0.12 & 0.63 \\
\hline Tangibility & 0.31 & 0.2 & 0.23 & 0.001 & .90 & 0.51 & -0.55 \\
\hline Liquidity & 1.77 & 1.38 & 1.21 & 0.27 & 7.78 & 2.01 & 4.56 \\
\hline Growth & 0.15 & 0.06 & 0.47 & -0.61 & 4.71 & 1.86 & 4.32 \\
\hline Business Risk & 0.07 & 0.02 & 1.27 & -7.07 & 8.46 & 0.04 & 13.69 \\
\hline Financial Flexibility & 0.05 & 0.02 & 0.17 & -1.02 & 0.73 & -2.71 & 9.74 \\
\hline Period 2009:2016 & & & & & & & \\
\hline Total Debt to Total Assets & 0.44 & 0.39 & 0.28 & 0.02 & 1.05 & 0.33 & -0.82 \\
\hline Long-Term Debt to Total Assets & 0.08 & 0.02 & 0.17 & 0.01 & 0.07 & 5.18 & 38.76 \\
\hline Short-Term Debt to Total Assets & 0.36 & 0.33 & 0.22 & 0.001 & 0.84 & 0.71 & 0.76 \\
\hline Profitability & 0.20 & 0.12 & 0.24 & -0.28 & 1.53 & 1.78 & 4.17 \\
\hline Size & 20.49 & 20.41 & 1.58 & 16.99 & 24.81 & 0.31 & -0.28 \\
\hline Tangibility & 0.25 & 0.22 & 0.19 & 0.000 & 0.83 & 0.79 & -0.07 \\
\hline Liquidity & & & & 4 & & & 1.37 \\
\hline Growth & 2.13 & 1.59 & 1.53 & 0.31 & 7.86 & 1.41 & 17.20 \\
\hline Business Risk & 0.11 & 0.03 & 0.61 & -0.89 & 9.83 & 10.57 & 1.54 \\
\hline Financial Flexibility & -0.14 & -0.11 & 1.54 & -8.22 & 8.41 & 0.15 & -3.00 \\
\hline Notes: This tab & 0.01 & 0.01 & 0.18 & -1.04 & 0.58 & 14.89 \\
\hline
\end{tabular}

Notes: This table reports the descriptive statistics, i.e. mean, median and standard deviation for our dependent and independent variables; the dependent variable is leverage measured as total debt over total assets and short-term debt over total assets; growth is measured as annual asset growth; size is natural log of total assets; profitability is measured as earnings before interest, taxes and depreciation to total assets; tangibility is measured as net fixed assets over total assets; liquidity is measured by the current ratio; business risk is measured as the percentage change of earnings before tax; financial flexibility is measured as the expected effect of retained earnings.

- For the period 2003:2016; the average total debt to total assets is $46 \%$, and the average short-term debt to total assets is $38 \%$. It can also be seen that Egyptian companies have an average rate of profitability $21 \%$, tangibility rate of $28 \%$, growth rate of $13 \%$, and a high liquidity of 2.60 averages.

- For the period from 2003:2008; the percentage of capital structure shown in this range of time has slightly increased to $48.6 \%$ for total debt to total assets, and $39.5 \%$ for the short-term debt to total assets. The average rate of profitability changed to be $22 \%$, tangibility rate become $31.1 \%$, growth rate increased to be $15 \%$, while the liquidity average slightly declined but still high liquidity at 1.77 .

- For the period 2009:2016; the percentage of capital structure shown in this sample has slightly declined to $43.8 \%$ for total debt to total assets, and $35.6 \%$ for the short-term debt to total assets. The average rate of profitability changed to be $20 \%$, tangibility rate become $25 \%$, growth rate declined to be $11 \%$, while the liquidity average slightly declined but still high liquidity at 2.13 .

The percentage of capital structure shown in the sample is relatively low around $45 \%$ for total debt to total assets, $37 \%$ for the short-term debt to total assets, and $8 \%$ for long-term debt to total assets. These percentages highly reveal 
that the financial managers in Egypt prefer to choose equity over debt as their first source of finance, then short-term loans over long-term ones, and the use of long-term debt comes as the last financing choice. Thus we focus only on both total debt to total assets and short-term debt to total assets as measures for capital structure.

The results of the descriptive statistics reflect that, over the fourteen-year time period, and after the division of this period into the three mentioned ranges of time, the financing behaviour of the managers in Egypt doesn't seem to change under crisis period from normal conditions. Under the three ranges of time, the financial managers in Egypt prefer the internal source as their first financing option, then the use of external funds preferring the use of short-term debt over the long-term debt.

In the descriptive analysis, it is apparent that few variables show a high level of both skewness and kurtosis. A skewness value of \pm 1.96 and a kurtosis value of \pm 2 are required for data to be considered normal (Abdul Rahman \& Ali, 2006). The descriptive results show that dependent variables (total debt to total assets and short-term debt to total assets) are normally distributed. On the other hands, the majority of the independent variables are normally distributed. Therefore, the important assumption of normality is not well satisfied. This is, however, expected in such types of studies as this one (Abdul Rahman \& Ali, 2006).

Tables 4 and 5 report the correlation matrix; whereas table 6 presents the VIF results using the total debt to total assets a dependent variable and the short-term debt to total assets as a dependent variable respectively. The pairwise correlation seems to be low between the explanatory variables so the possible problem of multicollinearity is eliminated. According to Leahy (2000), a possible multicollinearity problem is initiated from a correlation coefficient of 0.8; whereas Hair et al. (1995) and Gujarati (2003) recommended that correlation coefficient above 0.70 is considered the threshold at which multicollinearity concerns might be threatening for the regression analysis. None of these correlations were significant; since the correlations are lower than 0.70 .

Also, the VIF results presented in table 6 indicate that the regression equation is free of multicollinearity under all the three ranges of time as VIF is less than 5 .

Table 4. Pearson correlation coefficients TD/TA as constant

\begin{tabular}{|c|c|c|c|c|c|c|c|c|}
\hline Variables & TD/TA & FPROF. & FSIZE & FTANG & FLIQ. & FGRO. & FBRISK & FFLEX. \\
\hline \multicolumn{9}{|c|}{ Period 2003:2016 } \\
\hline TD/TA & 1 & 0.14 & 0.109 & -0.03 & -0.45 & 0.02 & -0.05 & -0.018 \\
\hline FPROF. & & 1 & -0.15 & -0.02 & -0.05 & -0.03 & 0.07 & -0.10 \\
\hline FSIZE & & & 1 & 0.21 & -0.21 & 0.10 & -0.05 & 0.17 \\
\hline FTANG. & & & & 1 & -0.12 & -0.03 & 0.02 & 0.08 \\
\hline FLIQ. & & & & & 1 & -0.01 & 0.03 & -0.001 \\
\hline FGRO. & & & & & & 1 & 0.01 & 0.04 \\
\hline FBRISK & & & & & & & 1 & 0.01 \\
\hline FFLEX. & & & & & & & & 1 \\
\hline \multicolumn{9}{|c|}{ Period 2003:2008 } \\
\hline $\mathrm{TD} / \mathrm{TA}$ & 1 & 0.20 & 0.03 & -0.15 & -0.53 & -0.04 & -0.04 & -0.29 \\
\hline FPROF. & & 1 & -0.06 & -0.01 & -0.11 & -0.09 & 0.09 & -0.29 \\
\hline FSIZE & & & 1 & 0.31 & -0.20 & 0.22 & -0.04 & 0.23 \\
\hline FTANG. & & & & 1 & -0.17 & -0.02 & 0.04 & 0.08 \\
\hline FLIQ. & & & & & 1 & 0.08 & 0.04 & 0.08 \\
\hline FGRO. & & & & & & 1 & 0.02 & 0.06 \\
\hline FBRISK & & & & & & & 1 & 0.02 \\
\hline FFLEX. & & & & & & & & 1 \\
\hline Period 200 & 2016 & & & & & & & \\
\hline
\end{tabular}




\begin{tabular}{|c|c|c|c|c|c|c|c|c|}
\hline TD/TA & 1 & 0.09 & 0.20 & 0.03 & -0.44 & 0.04 & -0.06 & -0.16 \\
\hline FPROF. & & 1 & -0.21 & -0.05 & -0.03 & 0.002 & 0.10 & -0.04 \\
\hline FSIZE & & & 1 & 0.17 & -0.28 & 0.04 & -0.09 & 0.18 \\
\hline FTANG. & & & & 1 & -0.10 & -0.05 & 0.04 & 0.07 \\
\hline FLIQ. & & & & & 1 & -0.03 & 0.02 & -0.01 \\
\hline FGRO. & & & & & & 1 & 0.003 & 0.02 \\
\hline FBRISK & & & & & & & 1 & 0.01 \\
\hline FFLEX. & & & & & & & & 1 \\
\hline
\end{tabular}

Note: the constant here is total debt to total assets. The table represents the pairwise correlation between the dependent and the independent variables.

Profitability found to have a non-significance correlation with leverage under the use of both measures of capital structure and under the three yearly ranges; same non-significance correlation were found in earlier studies (Omet and Mashharawe, 2004). Also, results show that size and tangibility are negatively related to profitability while growth is positively related to profitability. This may imply that larger firms in Egypt tend to have lower profitability levels, and profitable firms in Egypt tend to have less tangible assets. Also, the profitability, tangibility and growth variables have a positive correlation with short-term debt; and size has a negative correlation with short-term debt and total debt ratios. This implies that (1) Firms with high tangible assets levels, and growing firms tend to rely more on short-term debt. (2) Large and profitable firms are less likely to use short-term debt and tend to use less debt overall.

Moreover, the liquidity and business risk variables showed a negative relation with both total debt and short-term debt over all the three years ranges which implies that companies with higher liquidity and higher risk tends to use less debt overall. Also, financial flexibility showed negative relation with both total debt and short-term debt, which implies that companies prefer the use of internal source of finance over the use of debt.

Table 5. Pearson correlation coefficients for STD/TA as constant

\begin{tabular}{|c|c|c|c|c|c|c|c|}
\hline Variables $\quad$ STD/TA & FPROF. & FSIZE & FTANG & FLIQ. & FGRO. & FBRISK & FFLEX. \\
\hline \multicolumn{8}{|l|}{ Period 2003:2016 } \\
\hline $\begin{array}{ll}\text { STD/TA } & 1\end{array}$ & 0.16 & -0.06 & 0.17 & -0.41 & 0.02 & -0.05 & -0.04 \\
\hline FPROF. & 1 & -0.15 & -0.02 & -0.05 & -0.03 & 0.07 & -0.10 \\
\hline FSIZE & & 1 & 0.21 & -0.21 & 0.10 & -0.05 & 0.17 \\
\hline FTANG. & & & 1 & -0.12 & -0.03 & 0.02 & 0.04 \\
\hline FLIQ. & & & & 1 & -0.01 & 0.03 & -0.01 \\
\hline FGRO. & & & & & 1 & 0.01 & 0.04 \\
\hline FBRISK & & & & & & 1 & 0.01 \\
\hline FFLEX. & & & & & & & 1 \\
\hline \multicolumn{8}{|l|}{ Period 2003:2008 } \\
\hline $\begin{array}{ll}\text { STD/TA } & 1\end{array}$ & 0.13 & -0.21 & 0.35 & -0.46 & 0.17 & -0.05 & -0.06 \\
\hline FPROF. & 1 & -0.06 & -0.01 & -0.11 & -0.09 & 0.09 & -0.29 \\
\hline FSIZE & & 1 & 0.31 & -0.20 & 0.22 & -0.04 & 0.23 \\
\hline FTANG. & & & 1 & -0.17 & -0.00 & 0.04 & 0.08 \\
\hline FLIQ. & & & & 1 & 0.08 & 0.04 & 0.08 \\
\hline FGRO. & & & & & 1 & 0.02 & 0.06 \\
\hline
\end{tabular}




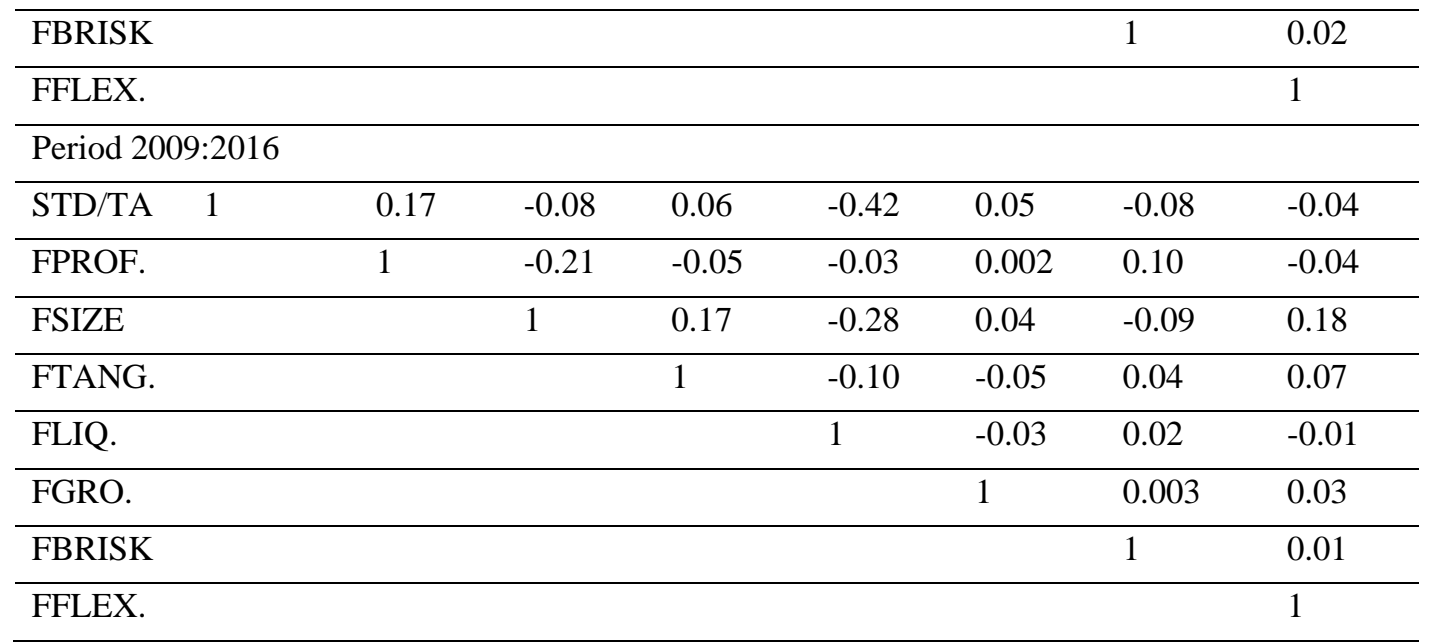

Note: the constant here is short-term debt to total assets. The table represents the pairwise correlation between the dependent and the independent variables.

Table 6. Firm level determinants of capital structure VIF results

\begin{tabular}{llll}
\hline VIF Test Results & Range of Time & \\
\hline Variable & $2003: 2016$ & $2003: 2008$ & $2009: 2016$ \\
\hline Profitability & 1.06 & 1.12 & 1.06 \\
\hline Firm Size & 1.14 & 1.28 & 1.21 \\
\hline Tangibility & 1.08 & 1.13 & 1.04 \\
\hline Liquidity & 1.09 & 1.10 & 1.10 \\
\hline Growth & 1.03 & 1.08 & 1.01 \\
\hline Business Risk & 1.03 & 1.02 & 1.02 \\
\hline Financial Flexibility & 1.02 & 1.16 & 1.04 \\
\hline Mean VIF & 1.06 & 1.13 & 1.07
\end{tabular}

Note: the regression equation is free of multicollinearity under all the three ranges of time as VIF $<5$.

\subsection{Main Results}

Table 7 presents the main regression results. Based on the OLS regression results, profitability, size, tangibility, liquidity, growth, business risk, and financial flexibility all found to be statistically significant using either the total debt to total assets or the short term debt to total assets as a dependent variable.

Table 7. OLS regression results of the firm level determinants of capital structure

\begin{tabular}{|c|c|c|c|c|c|c|c|}
\hline \multirow[t]{2}{*}{ Variables } & & $\begin{array}{l}\text { Equation } 1 \\
\text { TD/TA }\end{array}$ & $\begin{array}{l}\text { Equation2 } \\
\text { STD/TA }\end{array}$ & $\begin{array}{l}\text { Equation } 3 \\
\text { TD/TA }\end{array}$ & $\begin{array}{l}\text { Equation4 } \\
\text { STD/TA }\end{array}$ & $\begin{array}{l}\text { Equation } 5 \\
\text { TD/TA }\end{array}$ & $\begin{array}{l}\text { Equation } 6 \\
\text { STD/TA }\end{array}$ \\
\hline & & 2003:2016 & & 2003:2008 & & 2009:2016 & \\
\hline \multirow{4}{*}{ Constant } & Expected Sign & & & & & & \\
\hline & Coefficient & 0.3 & 0.71 & 0.55 & 1.028 & 0.02 & 0.378 \\
\hline & $\mathrm{T}$ & 3.45 & 9.16 & 5.09 & 11.062 & 2.56 & 3.15 \\
\hline & Sig. & 0.001 & 0 & 0 & 0 & 0.01 & 0.002 \\
\hline FPROF. & Expected Sign & + & + & + & + & + & + \\
\hline
\end{tabular}




\begin{tabular}{|c|c|c|c|c|c|c|c|}
\hline & Coefficient & 0.11 & 0.106 & 0.08 & 0.067 & 0.1 & 0.14 \\
\hline & $\mathrm{T}$ & 3.67 & 4.205 & 2.04 & 2.005 & 2.56 & 4.008 \\
\hline & Sig. & 0 & 0 & 0.04 & 0.046 & 0.01 & 0 \\
\hline \multirow{4}{*}{ FSIZE } & Expected Sign & + & + & + & + & + & + \\
\hline & Coefficient & 0.01 & -0.12 & 0.004 & -0.022 & 0.02 & -0.001 \\
\hline & $\mathrm{T}$ & 2.41 & -3.26 & 0.8 & -4.728 & 3.33 & -0.168 \\
\hline & Sig. & 0.02 & 0.001 & 0.04 & 0 & 0.001 & 0.06 \\
\hline \multirow{4}{*}{ FTANG. } & Expected Sign & + & - & + & - & + & - \\
\hline & Coefficient & -0.09 & 0.197 & -0.22 & 0.332 & -0.02 & 0.1 \\
\hline & $\mathrm{T}$ & -2.78 & 6.777 & -5.55 & 9.761 & -0.34 & 2.26 \\
\hline & Sig. & 0.01 & 0 & 0 & 0 & 0.07 & 0.024 \\
\hline \multirow{4}{*}{ FLIQ. } & Expected Sign & - & - & - & - & - & - \\
\hline & Coefficient & -0.02 & -0.021 & -0.05 & -0.048 & -0.02 & -0.16 \\
\hline & $\mathrm{T}$ & -14.6 & -14.973 & -12.99 & -13.95 & -9.87 & -10.017 \\
\hline & Sig. & 0 & 0 & 0 & 0 & 0 & 0 \\
\hline \multirow{4}{*}{ FGRO. } & Expected Sign & + & + & + & + & + & + \\
\hline & Coefficient & 0.01 & 0.006 & 0.01 & 0.032 & 0.01 & 0.013 \\
\hline & $\mathrm{T}$ & 0.46 & 0.53 & 0.45 & 1.996 & 0.7 & 0.943 \\
\hline & Sig. & 0.065 & 0.092 & 0.065 & 0.047 & 0.002 & 0.08 \\
\hline \multirow{4}{*}{ FBRISK } & Expected Sign & - & - & - & - & - & - \\
\hline & Coefficient & -0.04 & -0.049 & -0.01 & -0.032 & -0.05 & -0.082 \\
\hline & $\mathrm{T}$ & -1.24 & -1.678 & -0.27 & -0.832 & -1.34 & -2.07 \\
\hline & Sig. & 0.014 & 0.094 & 0.019 & 0.06 & 0.018 & 0.04 \\
\hline \multirow{4}{*}{ FFLEX. } & Expected Sign & - & - & - & - & - & - \\
\hline & Coefficient & -0.07 & -0.003 & -0.12 & -0.049 & -0.07 & -0.009 \\
\hline & $\mathrm{T}$ & -6.02 & -0.316 & -4.94 & -2.314 & -4.63 & -0.757 \\
\hline & Sig. & 0 & 0.02 & 0 & 0.02 & 0 & 0.05 \\
\hline \multicolumn{2}{|c|}{ Number of Observations } & 868 & 868 & 372 & 372 & 496 & 496 \\
\hline \multicolumn{2}{|c|}{ Adjusted R Square } & 0.850 & 0.500 & 0.793 & 0.675 & 0.738 & 0.465 \\
\hline \multicolumn{2}{|c|}{ Chi-Square } & 43.624 & 42.197 & 36.448 & 45.044 & 23.755 & 19.850 \\
\hline \multicolumn{2}{|c|}{$\begin{array}{lcc}\text { Chi-Square test } & \text { for } \\
\text { independence } & \text { P-value } & \end{array}$} & 0.00 & 0.00 & 0.00 & 0.00 & 0.00 & 0.00 \\
\hline \multicolumn{2}{|c|}{ Durbin Watson } & 2.229 & 2.038 & 1.978 & 1.924 & 2.413 & 2.143 \\
\hline
\end{tabular}

Note: Regression Method used is (Enter); dependent variables are total debt to total assets and short-term debt to total assets. D-W test significant at 2 per cent. Significance level is at $10 \%$.

According to the developed hypothesis, there's a significant relationship between profitability and leverage; the trade-off theory proposes a positive significant relationship whereas a negative significant relationship is consistent with the pecking order theory. The results show that there's a positive significant relationship between profitability and leverage (both total debt to total assets and short-term debt to total assets); the results are consistent the trade-off theory and with findings reported by (Antoniou et al., 2002; Rajan and Zingales, 1995 and A1-Sakran, 2001) that high profitable firms have lower bankruptcy risk and are more able to apply for and acquire more debt; whereas 
inconsistent with findings reported by (Bevan and Danbolt, 2002 and 2000; Pandey, 2001 and Booth et al., 2001) as well as the G7 nations results (Rajan and Zingales, 1995), the UK(Bevan and Danbolt, 2002), China (Chen, 2004), Jordan, Kuwait, Saudi Arabia and Oman (Omet and Mashharawe, 2004), the UAE (Ayyash et al., 2013) and the MENA region (Farooq, 2015).

The size of the firm is hypothesized to have a significant relationship with total debt to total assets and positive significant relationship with short-term debt to total assets. Both the trade-off and the agency cost theories propose a positive significant relationship between leverage and firm's size. While the pecking order theory proposes a negative significant relationship between leverage. The results show that there's a positive significant relationship between firm's size and total debt to total assets while a negative significant relationship with short-term debt to total assets, The results are consistent with findings reported (Agrawal and Nagarajan, 1990; Hovakimian et al., 2004; Du and Dai, 2005; Huang and Song, 2006; Eriotis et al., 2007; Al-Fayoumi and Abuzayed, 2009; Bae, 2009; Yu and Aquino, 2009; Ezeoha, 2011). The explanation for such positive relationship is that due to the diversifications in their resources, large firms tend to have less bankruptcy risk (Omet and Mashharawe, 2004); because of their low probability of bankruptcy, creditors tend to provide them with more funding. Moreover, large firms are usually less likely to be liquidated in financial distress cases (Ozkan, 2001). The positive relationship between size and leverage measured as total debt to total assets found to be consistent with results in G7 countries (Rajan and Zingales, 1995), Gulf countries (Omet and Mashharawe, 2004), Libya (Buferna et al., 2005), the UAE (Ayyash et al., 2013) and the MENA region (Farooq, 2015).

Thus, we accept both the trade-off and the agency cost theories and reject the pecking order theory. On the other hands, the negative relationship with short-term debt to total assets supports the fact that Egyptian companies prefer the use of short-term debt over long-term debt as it's a cheaper source of finance. This negative relation is consistent with the pecking-order theory proposition that firm size negatively affect leverage because large firms have more internal funds and thus tend to use less external sources of finance (Titman and Wessel, 1988).

Tangibility has been hypothesized to positively influence leverage, supported by the prediction of all of the capital structure theories (trade-off theory, pecking order theory, and agency cost theory). The results show that there's a negative significant relationship between tangibility and total debt to total assets, whereas a positive significant relationship with short-term debt to total assets. The result is consistent with findings from Rajan and Zingales (1995), Titman and Wessels (1988), Dess and Robertson (2003), Chen (2004), Faulkender and Petersen (2006) and Lemmon and Zender (2007); their results show a negative relationship between tangibility and total debt although their other findings support trade-off and agency cost theories. Same results regarding tangibility was found by Buferna et al. (2005) in their study on Libya although the findings support trade-off and agency cost theories; the negative relationship with total debt to total assets may indicate that companies in Egypt may not tend to use their fixed assets as collateral against debt. Whereas, the positive relationship with short-term debt may indicate that companies in Egypt follow the aggressive policy in using short-term debt in financing their fixed assets.

Consistent with the developed hypothesis, the results show that there's a negative significant relationship between liquidity and leverage (both total debt to total assets, and short-term debt to total debt to total assets), This result is relatively conforming with those of Omet and Mashharawe's (2004) study, who investigate the determinants of capital structure in Gulf countries (Saudi Arabia, Jordan, Kuwait and Oman) over the period 1996-2001. The trade-off theory suggests a positive relationship between debt and liquidity while both the pecking order and the agency cost theories propose a negative relationship between debt and liquidity. Therefore, we accept both the pecking order and the agency cost theories; and reject the trade-off theory.

According to the developed hypothesis, there is a significant relationship between growth and leverage, mainly positive with short-term debt. The pecking order theory proposes a positive significant relationship between debt and growth, whereas a negative significant relationship between debt and growth is consistent with the agency cost theory. The results show that there's a positive significant relationship between growth and leverage (both total debt to total assets and short-term debt to total assets), the result is consistent with the pecking order theory and the proposed hypothesis. Omet and Mashharawe (2004) argue that high-growth firms need to borrow more to finance this growth projects, their results show a positive relation between growth and leverage. Same results have been observed also in China (Chen, 2004) and Gulf countries (Omet and Mashharawe, 2004).

Business risk has been hypothesized to have a negative influence on leverage using both measures (total debt to total assets and short-term debt to total assets), as the three theories (trade-off theory, pecking order theory and agency cost theory) have agreed upon a negative significant relationship between debt and business risk. The results show a negative significant relationship which is consistent with Booth et al. (2001), De Jong et al. (2008) and Nadeem and 
Wang (2011). This may imply that the more variation in the earnings, especially negative, the more the probability of financial woes because the firm may not be able to meet its financial obligations.

Consistent with the developed hypothesis, the results showed a negative significant relationship between financial flexibility and leverage. The result is consistent with both the trade-off theory and the pecking order theory, and the suggestion Myers and Majluf, (1984) that firms with high level of financial flexibility tend to choose a capital structure that has a lower debt ratio as more profitable firms have less desire to external sources of finance. This means that, from the descriptions of the theories above, and based on the sample used for the research, the Egyptian companies conform to both the trade-off theory and the pecking order theory where financial flexibility was shown to negatively affect firm capital structure.

From the regression results, it's very obvious that neither the direction nor the significance have changed over the three ranges of times. Therefore, the results indicate that the financing behaviour of the financial managers in Egypt has been the same without any change over the studying period of time. However, the division of the 14 years into three ranges of time; the results show a significant relationship between the dependent variables and the independent variables. This may indicate that the neither the financial crisis (2008), nor the political and economic issues (2011-2014) have an effect on the financial managers behaviour in Egypt.

\subsection{Comparison Between Results From Egypt and Emerging Countries}

Although the results of studies about determinants of capital structure in Middle East countries are considered to be relatively old and out of date compared to this research, dividing the time period into three ranges allows us to compare at least the period prior to financial crisis (2003:2008) to results found from Middle East. The most comparable debt level to our results is in Oman and Jordan at 46.3 per cent and 37.7 per cent respectively (Omet and Mashharawe, 2004). Some variables were found to be significant factors for capital structure in Gulf countries; profitability, liquidity, size and growth opportunities are the same significant factors in in Egypt conforming to Omet and Mashharawe (2004). Although, tangibility is an insignificant determinant in Kuwait, Oman and Jordan, it's significant in our results conforming to the results of Libya (Buferna et al., 2005). The only finding that are inconsistent with the Gulf countries is the positive relationship between profitability and leverage.

The average leverage in Egypt seems to be relatively comparable to emerging countries such as Pakistan, Iran, Brazil and Turkey as well as Gulf countries specially Jordan and Oman. Profitability and size are also significant in India, Malaysia and Thailand (Booth and Aivazian, 2001). However, a significant negative relationship between tangibility and leverage is observed in Malaysia, Brazil and India (Booth and Aivazian, 2001).

In summary, the determinants of capital structure and the debt level in Egypt are relatively close and comparable to those of emerging countries, with similar institutional factors, indicating that these factors play a role in determining the capital structure; although they might not directly affect the capital structure as explanatory variables, they have influence on firm-level factors and hence financing decisions (Rajan and Zingales, 1995; Booth and Aivazian, 2001).

\section{Conclusion}

In this paper, we examine the firm level determinants of capital structure of non-financial firms in Egypt as a way to determine which one of the main three theories of capital structure better describe the financing decisions in Egypt for the period 2003-2016. The period has been divided into additional two ranges one prior to the financial crisis (2003-2008) and the other post the financial crisis and during the political and economic issues that took place is Egypt (2009-2016); in order to trace whether there has been any change in the preferences or the borrowing behaviour in Egypt.

The findings reveal that profitability, size, tangibility, liquidity, growth, business risk and financial flexibility are significant firm-level determinants. The sign and direction of profitability and size supports the trade-off theory, while the sign and direction of liquidity and growth supports the pecking order theory; whereas the sign and direction of business risk and financial flexibility supports both trade-off theory and the pecking order theory. This confirms that capital structure theories are conditional. As expected, the results are in line with those of other Gulf countries, although there are some differences compared to other developing countries, which supports the argument that countries within same geographic area tend to share similar financing behaviour (Kumar, Colombage and Rao, 2017).

Our results suggest that neither the financial crisis happened in 2008 nor the political and economic issues that took place in Egypt 2011-2014 affected the behaviour of the financial managers in Egypt whether positively or negatively. Our results provide a comprehensive overview of the capital structure in Egypt; this information will be of use to managers, shareholders and lenders. Future research can build on our study and extend it in several dimensions. Our 
empirical analysis can be extended using generalised methods of moments (GMM) model which we did not use because of data limitations. Further research is needed on the capital structure of unlisted Egyptian companies, as the focus has been mainly on listed companies.

\section{References}

Abdulla, Y. (2017). Capital structure in a tax-free economy: evidence from UAE. International Journal of Islamic and Middle Eastern Finance and Management, 10(1), 102-116.

Ahsan, T., Wang, M., \& Qureshi, M. A. (2016). Firm, industry, and country level determinants of capital structure: evidence from Pakistan. South Asian Journal of Global Business Research, 5(3), 362-384.

Al-Ajmi, J., Hussain, H. A., \& Al-Saleh, N. (2009). Decisions on capital structure in a Zakat environment with prohibition of riba: The case of Saudi Arabia. The Journal of Risk Finance, 10(5), 460-476.

Alipour, M., Mohammadi, M. F. S., \& Derakhshan, H. (2015). Determinants of capital structure: an empirical study of firms in Iran. International Journal of Law and Management, 57(1), 53-83.

Al-Sakran, S. A. (2001). leverage Determinants in the absence of Corporate Tax System: The Case of Non-financial Publicly traded Corporation in Saudi Arabia. Managerial Finance, 27(10), 58-86.

Altman, E. (1984). A Further Empirical Investigation of the Bankruptcy Cost Question. Journal of Finance, 39(4), 1067-1089.

Altman, E. (2002). Bankruptcy, Credit Risk, and High Yield Junk Bonds. Blackwell, Oxford.

Ang, J., \& Jung, M. (1993). An alternative test of Myers' pecking order theory of capital structure: the case of South Korean firms. Pacific-Basin Finance Journal, 1(1), 31-46.

Antoniou, A., Guney, Y., \& Paudyal, K. (2002). Determinants of Corporate Capital Structure: Evidence from European Countries.Working Paper, University of Durham.

Atkin, M., \& Glen, J. (1992). Comparing Corporate Capital Structure Around the Globe. The International Executive, 34(5), 369-387.

Ayyash, N., Chowdhury, R. H., \& Campbell, T. T. (2013). Relevance of capital structure theories in a tax-exempted economy: evidence from the United Arab Emirates. The Global Journal of Finance and Economics, 10(1), $25-40$.

Baker, M., \& Wurgle, J. (2002). Market Timing and Capital Structure. The Journal of Finance, LVII(1).

Baker, M., \& Wurgler, J. (2002). Market timing and capital structure. Journal of Finance, 57, 1-30.

Barclay, M., Smith, C., \& Watts, R. (1995). The Determinants of Corporate Leverage and Dividend Policies. Journal of Applied Corporate Finance, 7(4), 4-19.

Bas, T., Muradoglu, G., \& Phylaktis, K. (2009). Determinants of Capital Structure in Developing Countries. Working Paper, Cass Business School.

Bennett, M., \& Donnelly, R. (1993). The Determinants of Capital Structure: Some UK Evidence. British Accounting Review, 25(1), 43-59.

Bevan, A., \& Danbolt, J. (2002). Capital structure and its determinants in the UK a decompositional analysis. Applied Financial Economics, 12(3), 159-170.

Bevan, A., \& Danbolt, J. (2004). Testing for inconsistence in the estimation of UK capital structure determinants. Applied Financial Economics, 14(1), 55-66.

Booth, L., Aivazian, V., Demirguc-Kunt, A., \& Maksimovic, V. (2001). Capital structures in Developing Countries. The Journal of Finance, LVI(1), 87-130.

Bowen, R. M., Daley, L. A., \& Huber, C. C. Jr. (1982). Evidence on the Existence and Determinants of Inter-Industry Differences in Leverage Robert. Financial Management, 11(4), 10-20.

Bradley, G., Gregg, J., \& Kim, H. (1984). On the Existence of an Optimal Capital Structure: Theory and Evidence. Journal of Finance, 39(3), 857-878.

Brounen, D., Jong, A., \& Koedijk, K. (2004). Corporate Finance in Europe: Confronting Theory with Practice. Financial Management, 33(4), 71-101. 
Buferna, F., Bangassa, K., \& Hodgkinson, L. (2005). Determinants of capital structure: evidence from Libya. Working Paper, University of Liverpool.

Cassar, G., \& Holmes, S. (2003). Capital structure and financing of SMEs: Australian evidence. Journal of Accounting and Finance, 43(2), 123-147.

Castanias, R. (1983). Bankruptcy Risk and Optimal Capital Structure. Journal of Finance, 38(5), 1617-1635.

Charalambakis, E. C., \& Psychoyios, D. (2012). What do we know about capital structure: revisiting the impact of debt ratios on some firm-specific factors. Applied Financial Economics, 22(19/21), 1727-1742.

Chen, J. (2004). Determinants of capital structure of Chinese-listed companies. Journal of Business Research, 57(12), $1341-1351$.

Chipeta, C., \& Deressa, C. (2016). Firm and country specific determinants of capital structure in Sub Saharan Africa. International Journal of Emerging Markets, 11(4), 649-673.

Chirinko, R., \& Singha, A. (2000). Testing Static trade-off Against Pecking Order Models of Capital Structure: A Critical Comment. Journal of Financial Economics, 58(3), 417-425.

Drobetz, W., \& Fix, R. (2003). What are the Determinants of the Capital Structure? Some Evidence for Switzerland. Working Paper, The University of St. Gallen.

Ebaid, I. E.-S. (2009). The impact of capital-structure choice on firm performance: empirical evidence from Egypt. The Journal of Risk Finance, 10(5), 477-487.

Eldomiaty, T. I. (2008). Determinants of corporate capital structure: evidence from an emerging economy. International Journal of Commerce and Management, 17(1/2), 25-43.

Eldomiaty, T. I., Azim, M. H. (2008). The dynamics of capital structure and heterogeneous systematic risk classes in Egypt. International Journal of Emerging Markets, 3(1), 7-37.

ElKelish, W., \& Marshall, A. (2007). Financial structure and firm value: empirical evidence from the emerging market of the United Arab Emirates. International Journal of Business Research, 7(1).

Ellili, N., \& Farouk, S. (2011). Examining the capital structure determinants: empirical analysis of companies traded on Abu Dhabi stock exchange. International Research Journal of Finance and Economics, 67, 82-96.

Ezeoha, A. E. (2011). Firm versus industry financing structures in Nigeria. African Journal of Economic and Management Studies, 2(1), 42-55.

Fama, E. F., \& French, K. R. (2002). Testing trade-off and pecking order predictions about dividends and debt. The Review of Financial Studies, 15(1), 1-33.

Fan, J., Titman, S., \& Twite, G. (2003). An International Comparison of Capital Structure and Debt Maturity Choices. Working Paper.

Farooq, O. (2015). Effect of ownership concentration on capital structure: evidence from the MENA region. International Journal of Islamic and Middle Eastern Finance and Management, 8(1), 99-113.

Fattouh, B., Scaramozzino, P., \& Harris, L. (2003). Capital Structure in South Korea: A Quantile Regression Approach. Working Paper, Centre for Financial and Management Studies, University of London.

Fern, M., \& Jones, W. (1979). Determinants of Financial Structure: A New Methodological Approach. Journal of Finance, 34(3), 631-644.

Frank, M. Z., \& Goyal, V. K. (2008). Tradeoff and pecking order theories of debt. In E. Eckbo (Ed.), The Handbook of Empirical Corporate Finance. Elsevier, Amsterdam.

Frank, M. Z., \& Goyal, V. K. (2009). Capital Structure Decisions: Which Factors Are Reliably Important?. Managerial Finance, 24(10), 619-633.

Frank, M., \& Goyal, V. (2003). Testing the pecking order theory of capital structure. Journal of Financial Economics, 67(2), 217-248.

Gaud, P., Jani, E., Hoesli, M., \& Bender, A. (2003). The Capital Structure of Swiss companies: An empirical analysis using dynamic panel data. Working Paper, International Center for Financial Asset Management and Engineering. 
Ghazouani, T. (2013). The Capital Structure through the Trade-Off Theory: Evidence from Tunisian Firms. International Journal of Economics and Financial Issues, 3(3), 625-636.

Gleason, K., Mathur, L., \& Mathur, I. (2000). The Interrelationship between Culture, Capital structure, and Performance: Evidence from European Retailers. Journal of Business Research, 50(2), 185-191.

Gómez, G., Rivas, A. M., \& Bolaños, E. R. L. (2014). The determinants of capital structure in Peru. Academia Revista Latino Americana de Administración, 27(3), 341-354.

Graham, J., \& Harvey, C. (2001). The theory and practice of corporate finance: evidence from the field. Journal of Financial Economics, 60(2\&3), 187-243.

Hall, G., Hutchinson, P., \& Michaelas, N. (2004). Determinants of the Capital Structures of European SMEs. Journal of Business Finance \& Accounting, 31(5\&6), 711-728.

Hall, T. W. (2012, 2011). The collateral channel: Evidence on leverage and asset tangibility. The Journal of Corporate Finance, 18(3), 570-583.

Harris, M., \& Raviv, A. (1990). Capital Structure and the Information Role of Debt. Journal of Finance, 45(2), 321-349.

Harris, M., \& Raviv, A. (1991). The Theory of Capital Structure. Journal of Finance, 46(1), 297-355.

Huang, S., \& Song, F. (2002). The determinants of capital structure: Evidence from China. Working Paper, The university of Hong Kong.

Jensen, M. C. (1986). Agency Costs of Free Cash Flow, Corporate Finance, and Takeovers. American Economic Review, 76, 323-329.

Jensen, M., \& Meckling, W. (1976). Theory of the Firm: Managerial Behavior, Agency Costs and Ownership Structure. Journal of Financial Economics, 3(4), 305-360.

Keister, L. (2000). Capital Structure in Transition: Financial Strategy in China's Emerging Economy. Working Paper, The Ohio State University.

Koksal, B., Orman, C., \& Oduncu, A. (2013). Determinants of Capital Structure: Evidence from a Major Emerging Market Economy. Working Paper.

Korajczyk, R., \& Levy, A. (2003). Capital structure choice: macroeconomic conditions and financial constraints. Journal of Financial Economics, 68(1), 75-109.

Kumar, S., Colombage, S., \& Rao, P. (2017). Research on capital structure determinants: a review and future directions. International Journal of Managerial Finance, 13(2), 106-132.

Markopoulou, M. K., \& Papadopoulos, D. L. (2009). Capital Structure Signalling Theory: Evidence from the Greek Stock Exchange. Portuguese Journal of Management Studies, XIV(3).

Mathews, C., Vasudevan, D., Barton, S., \& Apana, R. (1994). Capital Structure Decision Making in Privately Held Firms: Beyond the Finance Paradigm. Family Business Review, 7(4), 349-367.

Modigliani, F., \& Miller, M. H. (1958). The cost of capital, corporation finance and the theory of investment. American Economic Review, 48, 261-297.

Mouamer, F. M. A. (2011). The determinants of capital structure of Palestine-listed companies. The Journal of Risk Finance, 12(3), 226-241.

Myers, S., \& Majiuf, N. (1984). Corporate Financing and Investment Decisions when Firms have Information that Investors do not have. Journal of Financial Economics, 13(2), 187-221.

Norton, E. (1990). Similarities and Differences in Small and Large Corporation Beliefs about Capital Structure Policy. Small Business Economics, 2, 229-245.

Nun, J. (2000). A study of capital structure in the UK: hotel and retail industries. Unpublished PhD Thesis, Surrey University.

Omet, G., \& Mashharawe, F. (2002, November). The Capital Structure Choice in Tax Contrasting Environments: Evidence from the Jordanian, Kuwaiti, Omani and Saudi Corporate Sectors. Faculty of Economics \& Administrative Sciences The Hashemite University, Jordan. 
Omet, G., \& Nobanee, H. (2001). The Capital Structure of Listed Industrial Companies in Jordan. Arabic Journal of Administrative Sciences, 8(2), 273-289.

Omran, M. M., \& Pointon, J. (2009). Capital structure and firm characteristics: an empirical analysis from Egypt. Review of Accounting and Finance, 8(4), 454-474.

Ooi, J. (1999). The determinants of capital structure Evidence on UK property companies. Journal of Property Investment \& Finance, 17(5), 464-480.

Ozkan, A. (2001). Determinants of Capital Structure and Adjustment to Long-Run Target: Evidence from UK Companies Panel Data. Journal of Business \& Accounting, 28(1\&2), 175-198.

Pandey, M. (2001). Capital structure and the firm characteristics: evidence from an emerging market. Working Paper, Indian Institute of Management Ahmedabad.

Qureshi, M. A. (2009). Does pecking order theory explain leverage behaviour in Pakistan?. Applied Financial Economics, 19(17), 1365-1370.

Qureshi, M. A., Imdadullah, M., \& Ahsan, T. (2012). What determines leverage in Pakistan? A panel data analysis. African Journal of Business Management, 6(3), 978-985.

Rao, S., \& Lukose, J. (2003). An Empirical Study on the Determinants of the Capital structure of Listed Indian Firms. Working Paper, Shailesh J Mehta School of Management, Indian Institute of Technology Bombay.

Rees, W. (1997). The Impact of Dividends, Debt and Investment on valuation models. Journal of Business Finance \& Accounting, 24(7\&8), 1111-1140.

Reynolds, T., \& Flores, A. (1989). Foreign Law: Current Sources of Codes and Basic Legislation in Jurisdictions of the World. Littleton, Cob, Rothman.

Ross, G. (1977). The Determination of Financial Structure: The Incentive Signalling Approach. Bell Journal of Economics, 8(1), 23-40.

Ross, S. (2007). Corporate Finance: Core Principles \& Applications. McGraw-Hill, New York, N.Y.

Sapar, S., \& Lukose, J. (2003). An Empirical Study on the Determinants of the Capital structure of Listed Indian Firms. Working Paper.

Sbeiti, W. (2010). The determinants of capital structure: evidence from the GCC countries. International Research Journal of Finance and Economics, 47, 55-81.

Sbeiti, W., \& Moosa, I. (2012). Firm specific factors as determinants of capital structure in the absence of taxes. Applied Financial Economics, 22, 209-213.

Scherr, F., Sugrue, T., \& Ward, J. (1993). Financing the small start-up: determinants for debt use. The Journal of Small Business Finance, 3, 17-36.

Scott, C. (1961). Research on Mail Surveys. Journal of the Royal Statistical Society SeriesA, 124(2), 143-191.

Serrasqueiro, Z., \& Caetano, A. (2013). Trade-Off Theory versus Pecking Order Theory: capital structure decisions in a peripheral region of Portugal. Journal of Business Economics and Management iFirst: $X X-X X$.

Shah, A., \& Khan, S. (2007). Determinants of capital structure: evidence from Pakistan panel data. International Review of Business Research, 3(4), 265-282.

Shahar, W. S., Bahari, N. F., \& Ahmad, N. W. (2015). A Review of Capital Structure Theories: Trade-off Theory, Pecking Order Theory and Market Timing Theory. International Conference on Management and Muamalah.

Shahjahanpour, A., Ghalambor, H., \& Aflatooni, A. (2010). The determinants of capital structure choice in Iranian firms. International Research Journal of Finance and Economics, (56), 167-175.

Sharma, S. A. (1996). Applies Multivariate Techniques. John Wiley \& Sons, USA.

Sharpe, S., \& Nguyen, H. (1995). Capital market imperfection and the incentive to lease. Journal of Financial Economics, 39(2-3), 271-294.

Sheikh, N. A., \& Wang, Z. J. (2011). Determinants of capital structure: An empirical study of firms in manufacturing industry of Pakistan. Managerial Finance, 37(2), 117-133.

Shyam-Sunder, L., \& Myers, S. C. (1999). Testing Static Tradeoff against Pecking Order Models of Capital Structure. Journal of Financial Economics, 51, 219-244. 
Singh, A., Hamid, J., \& Salimi, B. (1992). Corporate financial structure in developing countries. International Finance Technical Paper No 1, Washington, D. C., International Finance Corporation.

Titman, S., \& Wessels, R. (1988). The Determinants of Capital Structure Choice. Journal of Finance, 43, 1-21.

Titman, S., \& Wessels, R. (2000, March). The Determinants of Capital Structure Choice. The Journal of Finance, $\operatorname{XLIII}(1)$.

Urn, T. (2001). Determination of Capital Structure and Prediction of Bankruptcy in Korea. Unpublished PhD Thesis, Cornell University.

Vasiliou, D., Eriotis, N., \& Daskalakis, N. (2009). Testing the pecking order theory: the importance of methodology. Qualitative Research in Financial Markets, 1(2), 85-96.

Viviani, J. (2008). Capital structure determinants: an empirical study of French companies in the wine industry. International Journal of Wine Business Research, 20(2), 171-194.

White, H. (1980). A Heteroskedasticity-Consistent Covariance Matrix Estimator and a direct Test for Heteroskedasticity. Econometrica, 48(4), 817-838.

Wiwattanakantang, Y. (1999). An empirical study on the determinants of the capital structure of Thai firms. Pacific-Basin Finance Journal, 7(3\&4), 371-403.

Yu, D., \& Aquino, R. (2009). Testing capital structure models on Philippine listed firms. Applied Economics, 41(15), 1973-1990.

Zou, H., \& Xiao, J. Z. (2006). The financing behavior of listed Chinese firms. The British Accounting Review, 38(3), 239-258. 